\title{
マグネシウム合金 AZ31 圧延材の疲労特性に及ぼす湿度の影響 Effect of humidity on fatigue behavior of rolled magnesium alloy AZ31
}

$\begin{array}{cllllll}\text { O学 } & \text { 村山 } & \text { 義幸（長岡技術大院） } & \text { 学 } & \text { 伊藤 } & \text { 恵介（長岡技術大学） } \\ \text { 正 } & \text { 宮下 } & \text { 幸雄 (長岡技術大) } & \text { 正 } & \text { 大塚 } & \text { 雄市 (長岡技術大) } \\ \text { 正 } & \text { 武藤 } & \text { 睦治 (長岡技術大) } & & & \end{array}$

Yoshiyuki Murayama, Graduate student, Nagaoka Univ. of Tech

Keisuke Ito, Undergraduate student, Nagaoka Univ. of Tech

Yukio MIYASHITA, Nagaoka University of Technology

Yoshiharu MUTOH, Nagaoka University of Technology

Yuichi OTSUKA, Nagaoka University of Technology

KEY WORDS: Magnesium alloy, Fatigue, Corrosion

\section{1. 緒言}

マグネシウム合金は，他の金属材料と比較すると軽量で 比強度に優れ, リサイクル性も良好である. 現在, 軽量化 の要求が厳しい自動車の構成部材としての実用も進んでい る。しかし，これまでに報告1-3)されているようにその材料 特性から使用環境の影響を受けやすく，実用設計上，腐食 疲労が重要である。

本研究では, AZ31B 圧延材を供試材として高湿度環境中 ならびに疲労試験中に条件を変化させて疲労試験を行い, 疲労特性を調べた。

\section{2. 実験方法}

2.1 供試材および試験片 供試材として, AZ31B マグネ シウム合金圧延材 $(315 \mathrm{~mm} \times 333 \mathrm{~mm} \times 2.0 \mathrm{~mm})$ を用いた。供 試材の微視組織の観察例を Fig. 1 に, 化学組成を Table1 に示 す. 供試材の結晶粒径を切断法により測定した結果, 表面部 ならびに中心部いずれにおいても約 $17 \mu \mathrm{m}$ であった。引張試 験の結果を Table2に示す.引張試験は, クロスヘッドスピー ド $1.0 \mathrm{~mm} / \mathrm{min}$ の変位制御で行った。形状・寸法は JIS の 13

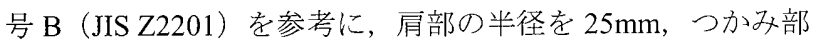
の幅を $30 \mathrm{~mm}$ とした。

疲労試験片は, Fig. 2 に示寸形状・寸法に, 機械加工によ り切出した. 試験片表面は, 600 番から 2000 番までのエメリ 一紙を順次用いて負荷軸方向に灯油を塗布しながら研磨仕 上げし, 試験片加工時の切削跡を完全に除去した状態で疲労 試験に供した。

\section{2 疲労試験疲労試験は, 容量 $10 \mathrm{kN}$ の電気油圧サーボ} 式疲労試験機（Shimadzu EHF-F1）を用いて行った。荷重制 御の精度を考慮し， $5 \mathrm{kN}$ のロードセルを取付けた。軸のアラ イメントは，表裏面にゲージ長さ $1 \mathrm{~mm}$ のひずみゲージを貼 り付けた試験片を準備し, 引張負荷を加え, ひずみの差が $5 \%$ 以内になるように調節した。疲労試験は荷重制御で行い, 荷 重波形は正弦波, 繰返し速度 $20 \mathrm{~Hz}$, 忘力比 $\mathrm{R}=0.1$ とした. 本実験では, (1)実験室環境, (2)高湿度環境, (3)環境サイクル 試験, (4)高湿度環境一実験室環境試験, の4 種類の環境で疲 労試験を行った。 (1)実験室環境試験では, 通常の実験室環境

において疲労試験を行った。試験中に温度およざ湿度を測定 した結果，それぞれ，11〜 $17^{\circ} \mathrm{C} ， 40 \sim 43 \% \mathrm{RH}$ 範囲であっ た。(2)高湿度環境試験は, 恒温恒湿環境槽を用いて, 温度 $50^{\circ} \mathrm{C}$, 湿度 $80 \%$ RHの条件で行った。 なお, 本実験では, 安定した 高湿度条件を得るため, 温度を $50^{\circ} \mathrm{C}$ とているが, 実験室環 境〜 $50^{\circ} \mathrm{C}$ 温度範囲では, 疲労挙動に影響がないことが報告 されている ${ }^{4)}$. (3)環境サイクル疲労試験は, 高湿度環境 $\left(50^{\circ} \mathrm{C}\right.$, $80 \% \mathrm{RH})$ における全寿命の $50 \%$ に相当する回数の疲労負荷 を高湿度環境中で加えた後, 実験室環境において同じサイク 儿数の疲労負荷を加える, という環境サイクルを, 試験片が 破断するまで繰返した。 (4)高湿度環境一実験室環境試験では, まず，高湿度環境 $\left(50^{\circ} \mathrm{C}, 80 \% \mathrm{RH}\right)$ における全寿命の $75 \%$ もしくは $50 \%$ に相当する回数の疲労負荷を高湿度環境下 $\left(50^{\circ} \mathrm{C}, 80 \% \mathrm{RH}\right)$ において加え, その後, 実験室環境に変え て，試験片が破断するまで疲労負荷を加えた。なお，(3)環境 サイクル試験および(4)高湿度環境一実験室環境試験におい ては, 環境条件のみを変化させ, 負荷応力振幅は変化させて いない。また，高湿度環境から実験室環境に変化させたとき には，試験片表面が乾燥し，また，䨌囲気の温度および湿度 が実験室環境と同一となったことを確認してから疲労負荷 を加えた。(2)高湿度環境試験, (3)環境サイクル試験および(4) 高湿度環境一実験室環境試験において, 実験室環境から高湿 度環境に変化させたときには，実験環境条件に到達した後， 恒温恒湿環境槽内の温度および湿度が安定するまで 15 分保 持し，その後試験を開始した。

\section{3. 結果および考察}

(1)実験室環境および(2)高湿度環境において行った疲労強 度試験の結果得られた $\mathrm{S}$ - N 曲線をFig.3に示す.同図より, 高湿度環境下においては, 実験室環境下と比較して, 低応 力・高サイクル領域において, 疲労強度の低下が認められた。 他方, 高応力・低サイクル領域においては, 高湿度環境の影 響は認められず，高湿度環境にお忖る疲労強度は実験室環境

Table1 Chemical composition (mass\%)

\begin{tabular}{|c|c|c|c|c|c|c|c|c|}
\hline $\mathrm{Al}$ & $\mathrm{Zn}$ & $\mathrm{Mn}$ & $\mathrm{Si}$ & $\mathrm{Fe}$ & $\mathrm{Cu}$ & $\mathrm{Ni}$ & $\mathrm{Ca}$ & $\mathrm{Mg}$ \\
\hline 3.12 & 1.04 & 0.36 & 0.020 & 0.001 & 0.002 & 0.0005 & 0.001 & bal. \\
\hline
\end{tabular}

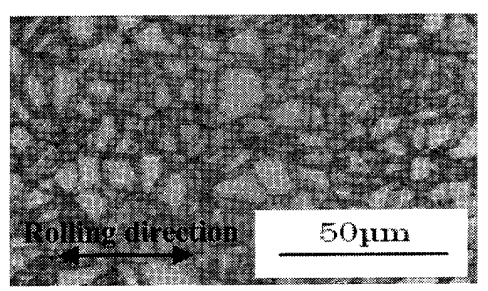

Fig.1 Microstructure of the material used

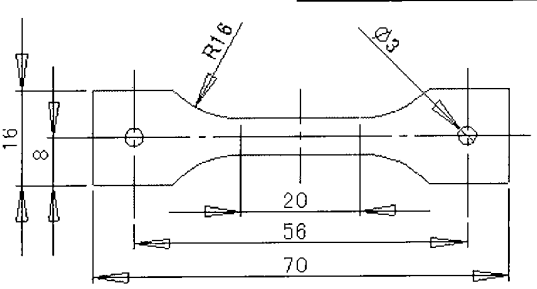

Fig.2 Geometry of the specimen for fatigue test.
Table2 Tensile properties for the material used.

\begin{tabular}{|c|c|c|c|}
\hline $\begin{array}{c}\text { Young's } \\
\text { modulus } \\
\text { (GPa) }\end{array}$ & $\begin{array}{c}0.2 \% \text { pro } \\
\text { of stress } \\
\text { (MPa) }\end{array}$ & $\begin{array}{c}\text { Tensile } \\
\text { strength } \\
\text { (Mpa) }\end{array}$ & $\begin{array}{c}\text { Elongation } \\
\%\end{array}$ \\
\hline 43 & 195 & 297 & 26 \\
\hline
\end{tabular}


における疲労強度とほぼ等しい。

(2)高湿度環境試験において，高応力・低サイクル領域およ び低応力・高サイクル領域において破断した試験片の破面お よび試験片表面観察例を Fig.4および 5 にそれぞれ示す. Fig.4 より，(2)高湿度環境試験において，高応力・低サイクル領域 で破断した試験片の場合, 破面上の疲労き裂起点部および試 験片表面には, 腐食疲労を示唆するような, 腐食ピットの発 生は認められなかった。他方, Fig.5 に示すように, (2)高湿 度環境において，低応力・高サイクル領域で破断した試験片 の場合, 破面上の疲労き裂起点部および表面に腐食ピットが 形成されていた。この腐食ピットの発生およびそこからのき 裂の発生は, (2)高湿度環境下における疲労寿命の低下を導く 一因と考えられる。なお，(1)実験室環境においては，負荷忘 力振幅レベルによらず, 疲労破壞起点部および試験片表面の いずれにも，腐食ピットの発生は認められなかった。

(3)環境サイクル試験および(4)高湿度一実験室環境試験の 結果をFig.6に示寸。同図中には, Fig.3に示した, (1)実験室 環境および(2)高湿度環境における実験結果を，それぞれ，破 線および一点鎖線で示している。(3)環境サイクル試験におい て, 試験片は, いずれも, 高湿度環境下で破断した。寿命を 比較すると，(3)環境サイクル試験においては，(4)高湿度環境 下よりも長寿命を示した。ただし，(3)環境サイクル試験にお いて，高湿度環境下で負荷したサイクル数を合計すると，(2) 高湿度環境試験において得られた寿命とほぼ等しかった。

Fig.6より，(4)高湿度一実験室環境試験においては，(2)高湿

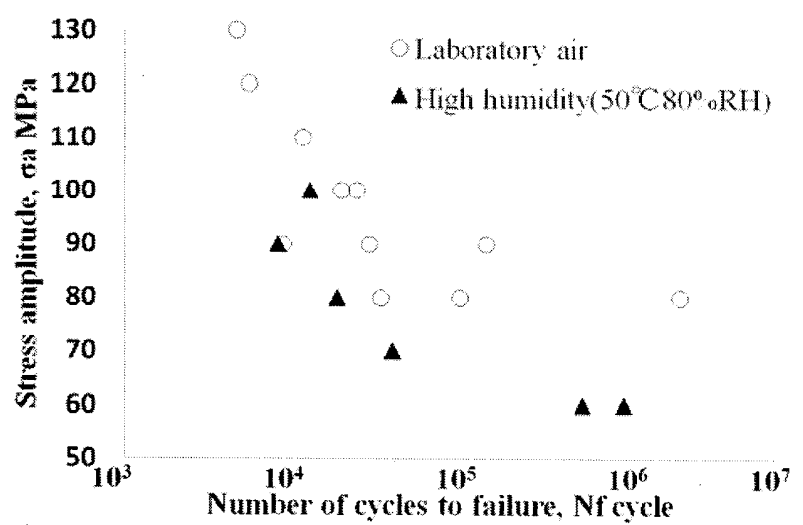

Fig.3 S-N curve obtain by fatigue test at (1) Laboratory Environment and (2) high humidity $\left(50^{\circ} \mathrm{C} 80 \mathrm{RH}\right)$.
度環境試験における全寿命の $75 \%$ および $50 \%$ に相当するサ イクル数の疲労荷重をはじめに高湿度環境にて負荷した場 合，いずれも，(2)高湿度環境下よりも長寿命を示した。ただ し, (1)実験室環境下と比較すると, 疲労強度は低下している. また，高湿度一実験室環境試験にお゙いて，75\%(Fig.6 中印) と $50 \%$ (Fig.6 中 $\square$ 印)を比較すると， $75 \%$ の方が短寿命を示 した. Zainuddinらは, AZ61 押出材を供試材とし, 本実験と 同様に $50^{\circ} \mathrm{C}, 80 \% \mathrm{RH}$ の条件で疲労試験を行っている ${ }^{4)}$. 報告 によると, 腐食ピットは全寿命のごく初期に発生し,さらに, 全寿命の約 $50 \%$ でピットからき裂が発生している. 本実験で は，ピットおよび疲労き裂の発生挙動の詳細は不明だが，ピ ットからのき裂発生寿命が同程度と仮定すると，高湿度環境 下において発生したピットから実験室環境下でき裂が発 生・進展した，もしくは，高湿度環境下においてピットから 発生したき裂が実験室環境下で引き続き進展して破壇に至 ったと考えられる。また，上述の(2)高湿度環境試験の結果， (4)高湿度環境一実験室環境試験において, 75\%(Fig.6中四印) の方が $50 \%$ (Fig.6 中回印)よりも寿命が短いこと，などを考 慮すると，環境 (高湿度) の影響は，腐食ピットの形成およ びその成長のみではなく，き裂進展挙動にも影響を及ぼして いる可能性が考えられる。

謝辞本研究は，新エネルギー・産業技術総合開発機構 (NEDO)平成 21 年度標準化調査事業による支援を受けた。

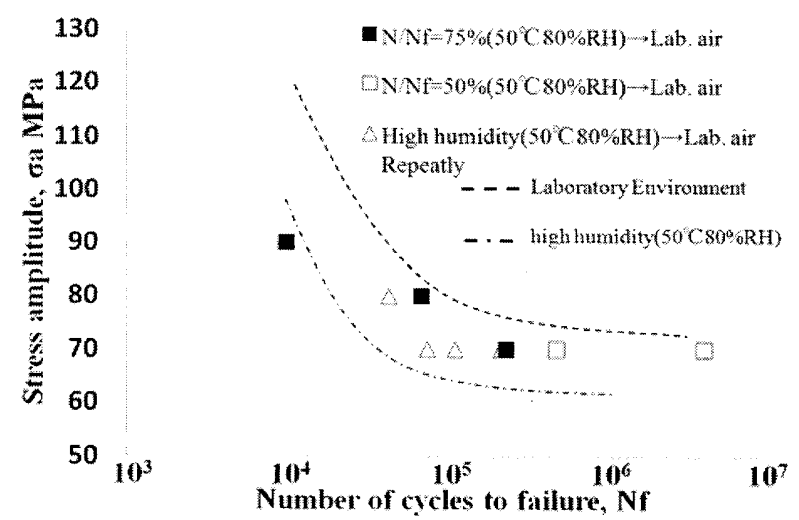

Fig.6 S-N curve obtain by fatigue test with (3)Environmental cyclic test. and (4)High humidity $\left(50^{\circ} \mathrm{C} 80 \% \mathrm{RH}\right) \rightarrow$ Lab. air test.
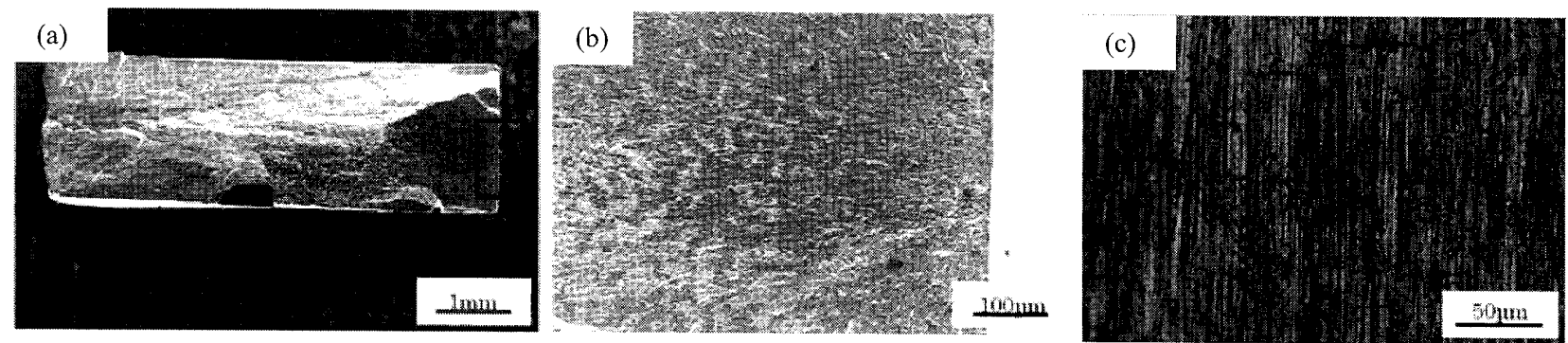

Fig.4 Observations of fracture surface(a),(b) and specimen surface(c), high humidity $\left(50^{\circ} \mathrm{C} 80 \% \mathrm{RH}\right), \quad \sigma_{\mathrm{a}}=100 \mathrm{MPa}, \quad \mathrm{N}_{\mathrm{f}}=13700 \mathrm{cycle}$
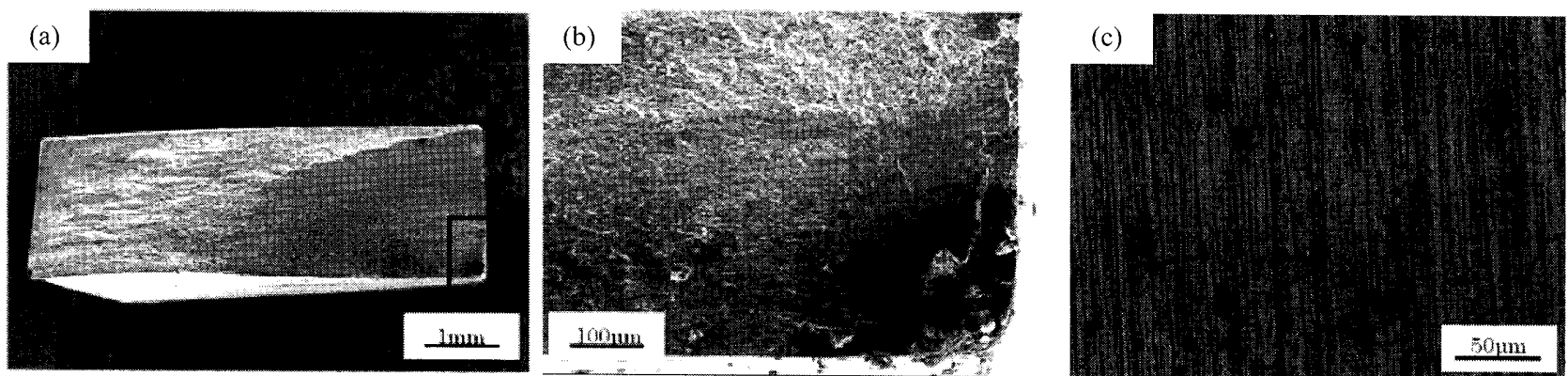

Fig.5 Observation of fracture surface(a),(b) and specimen surface(c), high humidity $\left(50^{\circ} \mathrm{C} 80 \% \mathrm{RH}\right), \quad \sigma_{\mathrm{a}}=60 \mathrm{MPa}, \mathrm{N}_{\mathrm{f}}=1153040 \mathrm{cycle}$ 